\title{
Practical theology as 'healing of memories': Critical reflections on a specific methodology
}

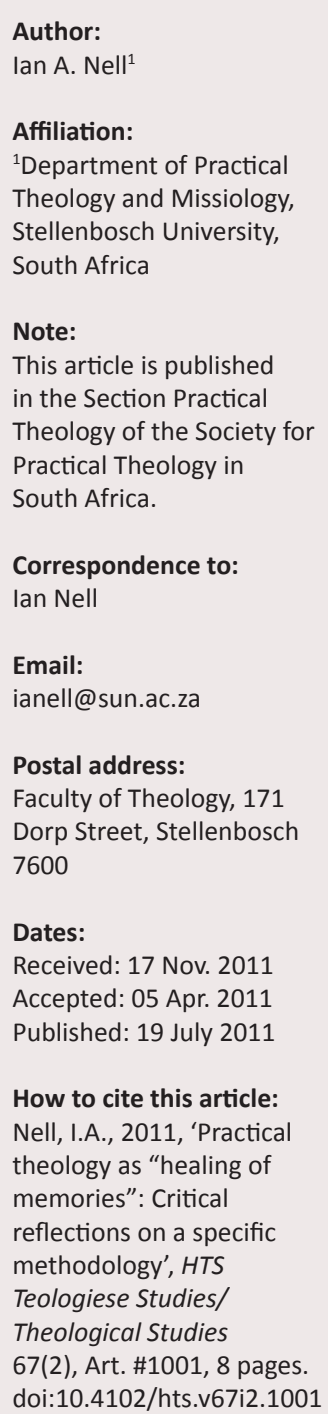

C 2011. The Authors. Licensee: AOSIS OpenJournals. This work is licensed under the Creative Commons Attribution License.
When developing new perspectives and paradigms for practical theology in South Africa, we obviously have to take our South African context seriously. We live in a post-conflict society in which gigantic sociocultural shifts have taken place since 1994. Many institutions and groups endeavour to address the conflict, injustices and pain of the past, including the Institute for the Healing of Memories (IHOM). The Institute makes use of a specific methodology in their workshops. Having participated in these workshops in congregational contexts as well as in the training of theological students, in this article I investigated the methodology of the Institute as a framework for new perspectives on practical theology in South Africa. Making use of Victor Turner's theoretical construct of 'social drama' as one way of looking at the methodology of the IHOM, I reflected critically on the challenges that it poses to practical theology by making use of a 'rhetorical frame' and trying to delineate some constructive proposals for further reflections on practical theological paradigms and perspectives.

\section{Introduction}

Postconflict South Africa is still a deeply divided country. At a recent conference on 'social cohesion' in Stellenbosch $^{1}$, Father Michael Lapsley, the director of the Institute for Healing of Memories (IHOM), stated:

'If we were to become one nation living together in peace and harmony we would have to listen to one another's
stories. Some of us began to set up safe and sacred spaces where we could speak and listen with the heart to one
another-places where we could vomit out the poison which had filled our hearts'. (Fr Lapsley, the director of the Institute for Healing of Memories 2009)

The Institute for the Healing of Memories (IHOM) endeavours to create such safe and sacred places, where people can tell their stories.

Fr Lapsley initially developed the Healing of Memories workshops whilst heading the Chaplaincy Project of the Trauma Centre for Victims of Violence and Torture. South Africa's past conflicts had led to a deeply divided society, where there is much suffering. Through his own experience of living in exile, losing both hands in a parcel bomb explosion and listening to the stories of the survivors whom he counselled at the Trauma Centre, Fr Lapsley became aware of the importance of giving people a space in which their experiences could be told and acknowledged.

He became a driving force in developing Healing of Memories workshops as an alternative form of providing support for victims and survivors of apartheid violence. At the time of South Africa's Truth and Reconciliation Commission (TRC) (1996-1997), it was obvious that only a few South Africans would have the opportunity to tell their stories to the Truth Commission. It was argued that platforms needed to be provided for all South Africans to tell their stories and be heard compassionately. The "Healing of Memories" workshops were run as a parallel process to the Commission, to facilitate reconciliation between the racial groups and to heal psychological wounds, making it possible for individuals to contribute effectively towards the reconstruction of South Africa. The workshops were also used to further support those who became overwhelmed by strong emotions whilst testifying. ${ }^{3}$

The vision of the Institute is to seek to contribute to the journeys of healing of individuals, communities and nations, whilst their mission is a commitment to:

- Facilitating the healing process of individuals and communities in South Africa and internationally.

1.The conference, with the theme 'Laying ghosts to rest with the audacity of hope' took place on 17 September 2009 and was a joint project of Stellenbosch University and the Municipality of Stellenbosch, initiated by Prof Russel Botman (Rector of the SU). The keynote speakers were Dr Mampele Ramphele, Father Michael Lapsley and Prof Russel Botman.

2.The title of his speech was Tortured, traumatised but not broken: The South African spirit and vision of hope

3.Information from the Healing of Memories website http://www.healingofmemories.co.za. 
- Remembering the apartheid years and healing the wounds.

- Redeeming the past by celebrating that which is life giving and laying to rest that which is destructive.

- Working in partnership with others who share our vision.

The institute approaches this as follows:

We do this to assist people on their journeys towards healing and wholeness within a safe space. We offer healing of memories activities such as workshops, seminars, talks and sermons. We are developing models for dealing with emotions such as anger, hatred and guilt and processes for reconciliation and forgiveness. We seek to be fully inclusive and respectful of diversity and of different faith communities and belief systems. ${ }^{4}$

(IHOM, 2011)

\section{Methodology}

In the light of the stated need and necessity for 'healing of memories' in a post-conflict South Africa, I will start by explaining the basic phases and constructs of social drama $^{5}$ as developed by Victor Turner (1974, 1982, 1986), followed by the description of the methodology ${ }^{6}$ of 'healing of memories'. At the same time, I try to read and interpret this methodology by making use of Turner's 'four acts' as lenses and also making use of some of the other concepts in his different contributions. In the last phase, I will make use of a 'rhetorical frame ${ }^{7}$ to make some suggestions about how these perspectives can help our reflections on perspectives and paradigms in practical theological work in South Africa.

\section{'Social drama'}

Victor Turner developed the theoretical construct of 'social drama' to study the dialectic of social transformation and continuity. 'Social dramas, then, are units of aharmonic or disharmonc process, arising in conflict situations' (Turner 1974:37). A few years later, he described social drama as 'a spontaneous unit of social process and a fact of everyone's experience in every human society' and another five years later once more defined it as 'an eruption from the level surface of ongoing social life, with its interactions, transactions, reciprocities, its customs making for regular, orderly sequences of behavior' (Turner 1986:196).

This drama, typically, 'has four main phases of public action, accessible to observation'. These four 'acts' can be summarised as follows: the first act is a 'breach of regular, norm-governed social relations' and it 'occurs between persons or groups within the same system of social relations'. It is, in other

4.The vision, mission and approach of the institute also from its website.

5.A new interest in the potential of drama comes from various areas, not only in respect of Practical Theology, but from all disciplines of Theology. See for example The New Testament: Wright (1992); Anderson (1988); Church History: Quash (2005); Systematic Theology: Brown (2008); Vanhoozer (2005); Von Balthasar (1998); Practical Theology: Osmer (2005); Childers \& Schmit (2008)

6.The methodology used here refers to a practical theological methodology making use of different practical theological tasks like the descriptive empirical, interpretive, normative and pragmatic tasks (cf. Osmer 2008). The methodology of the IHOM refers to the specific methodology under discussion in this article, described within refers to the specific methodology under
the theoretical construct of social drama.

7.For a renewed interest in the contribution of rhetoric to practical theological, see Keifert (2009). words, a rupture in social relations and is 'signalized by the public, overt breach or deliberate nonfulfillment of some crucial norm regulating the intercourse of the parties'. In this way, it becomes a kind of 'symbolic trigger of confrontation or encounter' and therefore, 'a dramatic breach may be made by an individual, certainly, but he always acts, or believe he acts, on behalf of other parties, whether they are aware of it or not. He sees himself as a representative, not as a lone hand' (Turner 1974:38).

The second act, is a crisis that cannot be handled by normal strategies:

Following breach of regular, norm-governed social relations, a phase of mounting crisis supervenes, during which, unless the breach can be sealed off quickly within a limited area of social interaction, there is a tendency for the breach to widen and extend until it becomes coextensive with some dominant cleavage in the widest set of relevant social relations to which the conflicting or antagonistic parties belong.

(Turner 1974:38)

This tendency for the breach to widen, sometimes referred to as the 'escalation of the crisis', forces representatives of order to grapple with it. It is a stage of turning points full of moments of danger and suspense, where people start to speak the truth about the real state of affairs and where it is no longer possible to wear masks and pretend that nothing is wrong. According to Turner, each public crisis has liminal characteristics, 'since it is a threshold between more or less stable phases of the social process ... but it is not a sacred limen, hedged around by taboos and thrust away from the centers? of public life' (Turner 1974:39).

The third act is a kind of remedy to the initial problem and functions as a redress and the re-establishment of social relations. This redressive action is meant to limit the spread of the crisis by making use of both informal and formal adjustive and redressive 'mechanisms', by leading representative members of the disturbed social system:

These mechanisms vary in type and complexity with such factors as the depth and shared social significance of the breach, the social inclusiveness of the crisis, the nature of the social group within which the breach took place, and the degree of its autonomy with reference to wider or external systems of social relations.

(Turner 1974:39)

These mechanisms may include a wide range of activities, from personal advice and informal mediation to the performance of public ritual. According to Turner (1974), a careful study of this phase is important and will include asking questions such as:

Whether the redressive machinery is capable of handling crises so as to restore, more or less, the status quo ante, or at least to restore peace among the contending groups. Then ask, if so, how precisely? And if not, why not?

(Turner 1974:40)

The final act can occur in two ways: 'reintegration of the disturbed social group or of the social recognition and legitimization of irreparable schism between contesting 
parties' (Turner 1974:41). What is of special interest for this article is that:

From the point of view of the scientific observer the fourth phase - that of temporary climax, solution, or outcome - is an opportunity for taking stock. He can now analyze the continuum synchronically, so to speak ... [of] the temporal character of the drama.

(Turner 1974:42)

In this phase, we have an alteration in the social arrangements (Turner 1982:149). It is important to note that in both reintegration and social recognition, there are symbolic displays in which actors show their unity and these displays often take the form of rituals. According to Turner's ritual theory, ritual can also be seen as a kind of plot that has a set sequence and therefore has a linear structure, not circular. In other words, ritual 'goes somewhere', rather than returning to where it began (Turner \& Turner 1978:161-163).

\section{The methodology of a 'healing of memories workshop'}

As explained in the introduction, these workshops seek to contribute to the healing journey of individuals, communities and nations, with a commitment to facilitate the healing process of individuals and communities in South Africa and internationally. The IHOM does this inter alia by helping individuals and groups to remember the apartheid years and venture to heal the wounds. This last sentence is of special importance because it is in this 'remembering' of a 'specific period' (apartheid) that one finds the trigger to the 'social drama', in Turner's terminology, the 'breach of regular, normgoverned social relations'. The following four 'acts' form part of the methodology.

\section{A real life drama (breach)}

Normally, the workshops take place over a weekend in an 'island setting'. ${ }^{8}$ The IHOM has a number of trained facilitators, with one person acting as coordinator of the facilitation team. The workshop begins with a welcoming session, in which each of the participants ${ }^{9}$ gives some indication of their expectations on a piece of paper. In this exercise, the first signs of a looming 'breach' already surface. A White, Afrikaans-speaking theological student (age 23) in a recent workshop wrote the following on his piece of paper:

'I hope that my expectations won't be fulfilled. I suspect it will turn out to be a "sorry for apartheid" exercise. Although I know that dialogue is important and that we must not forget our history, I feel, more and more, it is a case of the children having aching stomachs because their fathers ate sour grapes. I did not gain anything from apartheid. Leave me alone!'

(Workshop student, [author's own translation])

This is already an indication of the potential of a 'rupture in social relations'. These different expectations are posted

8.That is, synthetic isolation from the everyday world and its distractions.

9.The participants in this workshop was the M.Div class of 2009. Since 2000, the Faculty of Theology at the University of Stellenbosch is an ecumenical faculty including students from the Dutch Reformed Church (DRC), United Reformed Churn of south Africa (URCSA) and sevol other Church of South Africa (URCSA) and several other denominations. The class of 2009 included Afrikaans-speaking students from the DRC and URCSA, as well as Xhosaspeaking students. Eight of the twenty-two students were female. on a wall. Then, the 'Mina Nawe' drama group is introduced to the participants. The seven Xhosa-speaking women are a volunteer group of amateur dramatists from Khayelitsha, performing this drama on a voluntary base for the past ten years. The drama takes one back to the life and circumstances in the mid 1980s, with South Africa in a 'state of emergency'. The Security Police is keeping law and order in the townships. They are heavily armed with armoured vehicles and automatic rifles and firing on protesters, creating havoc. A young girl is shot in front of her mother followed by communal weeping at the loss of life.

The actors move in and out of the circle, making use of songs, dialogue and interaction with the audience, so much so that the division between actors and audience starts to disappear. The members of the audience become participants in this drama depicting a dramatic period in South Africa's history. At the end of the drama, the main character gives a short summary of the reasons for the existence of the group and her personal motivation for participating in the group.

\section{Conversation in big group (crisis)}

With the act of the drama fresh in the memory, the coordinator of the facilitation team of the IHOM asks the group to reflect on the feelings they experienced during the drama. At our last workshop, one of the first responses came from a female Xhosa-speaking student. She grew up in a township in the Eastern Cape and told the group how she was witness to an incident where the Security Police shot her mothers' sister in front of her eyes. The drama took her back to that tragic incident and brought back memories of pain and injustice.

It is obvious that this is a phase of mounting crisis with a widening breach; nothing less than an escalation of the crisis forcing the group and the facilitators to reflect and to grapple with the acts they have seen and the words they have heard. This student was not the only witness to what happened during the 1980s in townships all around our country. Student after student from the Coloured and Black communities told stories from their youth, with White students listening, but (at least in some cases) with little comprehension of a world they do not recognise and cannot identify with.

One realises that this is indeed a stage of turning points, rife with moments of danger and suspense, where people start to speak the truth about the real state of affairs and where it is no longer possible to wear masks and to pretend that nothing is wrong (Turner 1974:39). The evening ends with questions to the group. These questions pertain to experiences the group had whilst watching (and participating in) the drama. Questions like: Could you identify with the pain and loss of the characters? What emotions did you experience whilst watching the drama group? What in the act can you use when you reflect on your own history? What influence did these events have in your life story?

\section{Creative exercise and narrative (redressive action)}

The activities of the next morning start with a creative exercise, in which each participant is expected to make a drawing 
of their 'river of life'. The drawing is carried out on a large piece of paper, using colouring crayons. The participants can draw whatever they like to picture incidents in their life in which they experienced joy or sorrow, pain or exclusion. The only prerequisite is that they are not allowed to use words on the paper. The purpose of the exercise is to make use of the creative side (right brain activity) to draw pictures rather than verbal descriptions of life stories. Another purpose is to give the opportunity for feelings and emotions to flow through the fingertips onto the piece of paper as part of the 'healing process' in dealing with underlying guilt, emotions of sorrow, anxiety, frustration and so forth.

After allowing an hour for the creative exercise, the big group is divided into smaller groups, with not more than five persons per group, which includes a facilitator. There is a formal agreement that information that the participants share in the small group will be kept confidential and will not be shared with anybody else. For the rest of the day, each participant in the small group receives the opportunity to tell their story, by explaining their drawing to the rest of the group. This is an exercise in listening, as each participant is allowed 45 minutes to tell their story; the others are not allowed to interrupt or to ask questions whilst the person is busy narrating. No one is forced to narrate or to deal with emotions and events that they do not feel comfortable with. After listening to each one's story, there is time for reflection and the opportunity to ask the person questions.

It is obvious that in terms of Turner's third act (1974:39-40), the act of drawing and storytelling is a kind of remedy to the initial problem and functions as a redress and the reestablishment of social relations. In the discussion of his theory, we saw that this redressive action is meant to limit the spread of the crisis by making use of adjustive and redressive 'mechanisms', both informal and formal, by leading representative members of the disturbed social system. The creative exercise (drawing) and the accompanied storytelling can be called 'adjustive and redressive mechanisms' insofar as they function not only to limit the spread of the crisis, but also try to understand the underlying reasons for the 'disturbed social system'.

Another important aspect that Turner (1974) helps us to keep in mind in this regard is that:

These mechanisms vary in type and complexity with such factors as the depth and shared social significance of the breach, the social inclusiveness of the crisis, the nature of the social group within which the breach took place, and the degree of its autonomy with reference to wider or external systems of social relations.

(Turner 1974:39)

These mechanisms may include, as explained above, a wide range of activities. The creative exercise and storytelling can also be supplemented with personal advice and informal mediation as well as the performance of public ritual, which takes us to the last act.
In this regard, it is also important to remember that according to Turner (1974), a careful study of this phase is very important and will include questions like:

Whether the redressive machinery is capable of handling crises so as to restore, more or less, the status quo ante, or at least to restore peace among the contending groups. Then ask, if so, how precisely? And if not, why not?

(Turner 1974:40)

This brings us to the last phase.

\section{Festivity and liturgy (reintegration)}

After a full day of 'active listening' and the emotional hard work of narrating life stories by making use of the drawings, the process asks for 'breathing space', which takes place through two related activities. The first activity is scheduled for the evening after the creative exercise and storytelling in the form of an informal social gathering, with a mood of festivity and light-heartedness. Dealing with emotional hardship drains energy and everybody in the group needs to 'surface and find some fresh air' after dealing with pain and sorrow from the past. Music, wine and food provide the opportunity for this informal socialising, knowing that it has been a hard day for every participant.

The second activity takes place on the last morning of the workshop, a 'public ritual' in the form of a participatory liturgy. The whole group convenes under the guidance of the coordinating facilitator. The group decides on the central theme of the liturgy and with the input of each and every one, a liturgy is composed that will be performed giving all the participants the opportunity to contribute in one way or another.

Another two creative exercises form part of the preparation for the liturgy. Each participant receives a piece of clay that they have to use to create a peace symbol to present to the rest of the group during the liturgy. Whilst presenting it to the group, the member gives a short explanation of what they created and lights a candle for someone they care for. The second exercise in creativity is a short drama that each small group has to perform during the liturgy. This can be in the form of a mime, a song, a dialogue or anything else the group wants to use to present something of their experience of reconciliation and peace.

After the completion of the communal liturgy, the coordinator of the facilitation team gives some time for reflection on the whole workshop, by asking whether the participants' expectations (still on the wall) have been fulfilled. The evaluation takes place in the form of an open discussion, but also by making use of a standard evaluation report to be completed before the group disperses.

The activities just described form part of Turner's final act (1974:41), which can occur in two ways: 'Reintegration of the disturbed social group or of the social recognition and legitimization of irreparable schism between contesting 
parties'. It is also, in Turner's words, 'an opportunity for taking stock'. It creates the possibility of synchronically analysing the continuum of the temporal character of the drama.

We saw in the discussion of this phase in Turner's theory that we have an alteration in the social arrangements (1980:149). Turner and Turner (1978:161-163) also underlines the importance of ritual during this phase by pointing out that in both reintegration and social recognition, there are symbolic displays in which actors show their unity and these displays often take the form of rituals. The fact that in Turner's ritual theory ritual is seen as a kind of plot that has a set sequence and therefore a linear structure, can also be applied to the communal liturgy during the Healing of Memories workshop. In other words, as already stated, ritual 'goes somewhere' rather than returning to where it began.

\section{Critical reflections}

To help with the critical reflection, I will make use of a 'rhetorical frame', ${ }^{10}$ which I find helpful not only to complement the social drama theory of Turner, but also to order some thoughts on practical theological ${ }^{11}$ paradigms and perspectives.

\section{Pathos: The world to which theology acts (speaks)}

Thus, pathos has to do with the condition, frame of mind and circumstances of the audience and is also related to everything the audience contributes to the rhetorical situation. The process of persuasion must begin with what we can refer to as 'common ground'. According to Burke (1969:55), we need to identify with them; 'we persuade others by speaking their language, identifying our ways with theirs':

According to Aristotle, one of the three means of persuasion is pathos, or 'putting the hearer into an appropriate frame of mind'. He explains that persuasion occurs 'by means of the hearers, when they are aroused to emotion (pathos) by the speech; for the judgments we deliver are not the same when we are influenced by joy or sorrow, love or hate'.

(Cunningham 1990:42)

I believe that herein, as part of critical reflection with a view to the development of new perspectives for practical theology, lies a major challenge for practical theology in South Africa. The so-called 'breach' and 'crisis' of Turner's 'social drama' theory is about the ability or inability to identify with the audience. Bearing in mind the diverse cultures, contexts and socioeconomic contexts of the people in our country, pathos requires particular exertion and creativity. Often, what seems obvious to one group is an obstacle for others. The recent public discourse about marriage (cohabitation and polygamy) is a typical example.

10.'According to Aristotle, rhetoric is not so much an art or science as a faculty. This makes rhetoric an excellent candidate for application in other fields' (Cunningham 1990:27).

11.One can define practical theology in many different ways. I find the definition of Osmer (2005) helpful: 'Practical theology is that branch of Christian theology that seeks to construct action-guiding theories of Christian praxis in particular social contexts' (Osmer 2005:viv).
As a result, the challenge for a rhetorical approach is to try to find a balance between the need to identify (which just confirms the presuppositions of the audience and does not lead to change) and the expectation of immediate change and adjustment (which can alienate the audience). Therefore, new possibilities that can help with the processes of 'identification' will have to be developed for the IHOM workshops. Regarding methodology, one can for instance question whether the drama of the apartheid years still creates the necessary 'identification' or whether it doesn't perhaps increase the 'breach' in certain groups to the extent that further persuasion becomes impossible.

If we are serious about social cohesion or inclusion 'to resolve the race and class polarizations within the population and to form and build a united nation within a unitary state in which justice and equity are leading values' (Cloete \& Kotze 2009:3), as the government has been propagating strongly since 1994, then initiatives like the IHOM workshop will have to operate between said extremes to make persuasion a reality.

It will therefore be worthwhile to take the different modern perspectives on the audience ${ }^{12}$ and the three 'publics' suggested by Tracy (1981:13), seriously. According to Cunningham (1990:68), however, this is not enough for a clear understanding of the audience. Both work with two basic presuppositions, firstly that the audience is simply 'out there', waiting to be addressed; and secondly, if rhetors wish to take account of the audience, they must somehow discover, with certainty and finality, what makes the audience 'tick'.

For practical theology in its striving for 'healing of memories', more is needed; therefore, it is important that the rhetor (practical theologian) can construct an audience that complies with the circumstances. If Sunday morning is still the most segregated hour in South Africa and racial reconciliation the unfinished business for theology in our country, ${ }^{13}$ it is important to understand how important the role of the speaker (practical theologian) is in the construction of his or her audience. Cunningham (1990) summarises it as follows:

More precisely: Speakers and writers construct their audiences through the very way in which they select and deploy their arguments. By choosing certain arguments over others, rhetors include and exclude certain people from the audience.

(Cunnigham 1990:69)

The construction of this audience is undoubtedly part of the 'unfinished business' of practical theology in SA and social drama and rhetorical perspectives can help us in constructing an audience that is adequate for each specific occasion.

12.See also the perspectives discussed by Cunningham (1990:53-64), namely the intentionalist persepctive, the empiricist perspective, the pluralist perspective and the idealist perspective.

13.'Sunday Morning - The Most Segregrated Hour: On racial reconciliation as unfinished business for theology in South Africa and beyond'. Inaugural lecture delivered upon accepting the position of VU University Amsterdam Desmond Tutu delivered upon accepting the position of VU University Amsterdam Desmond Tutu
Chair holder in the areas of Youth, Sports and Reconciliation, at the Faculty of Theology of VU University Amsterdam on 07 October 2009. 


\section{Ethos: The character with which theology acts}

According to Aristoteles, a second way in which persuasion takes place is based on the moral character (ethos) of the speaker (practical theologian) ${ }^{14}$ and the speaker's character will influence the degree of trust with which a speech is accepted. So 'faithful persuasion' is about more than the construction of the audience and the clever use of arguments.

\section{Heidegger (1977) understands ethos as follows:}

Ethos means abode, dwelling place. The word names the open region in which man dwells. The open region of his abode allows what pertains to man's essence, and what in thus arriving resides in nearness to him, to appear.

(Heidegger 1977:233)

A person's ethos involves a wide variety of activities and passions, in other words, how that person approaches life.

For practical theologians however, the character of God is of central interest, especially the character of Jesus Christ, who came to this world as a specific person and called us to identify with Him and follow Him as disciples. Throughout the ages, theology has thus been interested in character, visibly in Paul's letters, the early church fathers and throughout the Middle Ages. But it was during the Enlightenment that the persuasive role of character was devalued by the concepts of 'neutrality' and 'objectivity' as criteria for true scientific character. As with pathos, the character of the speaker (ethos) is a 'constructed reality'. 'It is not an essence, waiting to be truthfully revealed; rather, it is actively constructed by a particular audience in a specific rhetorical context' (Cunningham 1990:146).

If we return to the significance of 'healing of memories' for practical theology and the IHOM workshop as example, the construction of the characters of various speakers clearly plays a role. At least the characters of the person who organised the workshop, the performance of the drama group and the various facilitators are relevant. Turner's 'social drama' helped us to see that the so-called 'rupture in social relations' leading to the 'breach' is directly related to the distrust amongst people in the mutual construction of others' characters. In the evaluation of one of the workshops a student wrote:

'The way the workshop was presented helped me to see the importance of sharing in each other's stories. We can hardly expect to get along, understand each other in debates or work together without properly knowing each other, knowing where we come from and what has made us the way we are. In sharing each other's highs and lows, joy and pain, we begin to walk with the other person and begin to understand a little of how that person works. In listening to their stories, seeing their pictures and their clay peace symbols, I began to understand their pain and sadness ... We are all hurt and bruised in some way and that causes us to act or react in ways that hurt other people or that other people can't understand, but after travelling with others we begin to understand them better...'

(Workshop student)

Emeritus Archbishop Desmond Tutu recently said at a conference: 'In very recent times we have been afforded some dramatic and often deeply distressing examples of failed leadership, or indeed what we should without equivocating call unethical leadership ${ }^{\prime 15}$, clearly illustrating the enormous challenge of ethos (moral character) for practical theology. For 'healing of memories' to take place it is indeed necessary, as the student mentioned, to be able to trust one anothers' characters, spend time in one anothers' presence and learn to know one anothers' cultures. This brings us to the third and last aspect that forms part of the importance of a rhetorical framework for practical theology, logos.

\section{Logos: The acts of theology}

The third aspect of the rhetorical situation is according to Aristotle the argument itself: 'Persuasion is produced by the arguments (dia ton logon) themselves, when we establish the true (alethetes) or apparently true (phainomenon) by the means of persuasion applicable to each individual case ${ }^{\prime} .{ }^{16}$ The reason why logos (argument) is dealt with last, has to do with the fact that arguments are not absolute structures that merely reflect the natural order of things, but function differently in different rhetorical situations and therefore cannot simply be transferred from one context to another (Cunningham 1990:148).

Logos as arguments in a rhetorical context are interpreted widely and include more than just words. As a result, not only the various sources of Christian theology (like the Bible, tradition, reason and experience) are used to expand the conceptual framework of arguments, but also nonlinguistic forms. Ultimately, both words and deeds (praxis) lead to persuasion.

\section{Cunningham (1990) summarises as follows:}

God's rhetorical activity is revelation; human rhetorical activity is proclamation. The difference between the two categories is significant. But their difference should not distract us from the fact that they do intersect - at a single point ... Thus, the ultimate rhetorical event in Christian theology, the ultimate word which theology speaks, is called, quite properly, the Word - who became flesh and dwelt among us, full of grace and truth.

(Cunningham 1990:203)

Returning to the IHOM workshops, it is in the creative exercises, narratives, festivity and liturgy that we discover the logos as different acts within the rhetorical framework. Thus, creative activities, narratives and participation in these various forms of praxis result in the liturgy, where 'faithful persuasion' occurs. Redressive action (in Turner's theory) is the altered praxis practical theologians are searching for. I believe the potential of these workshops is that it makes use of a variety of arguments (logos as different forms of praxis), consisting not only of logical arguments, but also addressing other faculties of the human spirit.

There are imaginative creative activities, time for reflection and meditation, re-interpretation and telling of stories from

15.A paper delivered at the Seboka Conference at the US, April 2008: 'The role of moral and ethical leadership in transforming society: Challenges for Southern Africa'.

16.Aristotle Rhetorics (1356a:19-21). 
the past, celebration of life through festivity and worshipping God through the liturgy, all of which forms part of recovery, of the healing of memories, of reconciliation and justice. It is of particular significance that the workshops end with liturgical activities. Lewis (2003), reflecting on Turner's concept of 'social drama' helps us to understand the importance of this when he writes:

The third, redressive phase took on the greatest weight in his theorizing, since he argued it was from this process that most rituals and ultimately most other kinds of regulated special events developed. The picture that emerges, at least from one central aspect of Turner's work, is of an ordered social system that is disrupted dramatically, and from this disruption people create rituals ... to try to restore order. In doing so they must reflect on who and what they are (as group and as individuals), and out of these reflexive performances social change may also be generated.

(Lewis 2003:43)

In the discussion of the methodology of the IHOM workshops, it also became apparent that it is this third phase, which also took up most of the time of the workshops, that the participants were forced to reflect on 'who' they are as group and as individuals. Once again, it is important to note that it is during this phase that the central role of ritual come to the fore; ritual here broadly depicted in the form of creative exercises, storytelling, festivity, clay peace symbols and participatory liturgy.

\section{Conclusion}

To summarise, I think the discussion of the methodology of the IHOM workshops (by making use of Turner's concept of 'social drama' and Aristotle's 'rhetorical frame' for interpreting these events) open up some fresh perspectives on practical theology within a South African context.

If practical theologians are serious about 'social cohesion' in order to 'resolve the race and class polarizations within the population and to form and build a united nation with a unitary state in which justice and equity are leading values' (Cloete \& Kotze 2009:7), the healing of memory workshops are important tools in realising this goal. It is important to listen to one another's stories, be it in communities of faith, amongst students busy preparing for ministry or amongst people in other working environments, like municipalities or state departments, by giving people a 'safe space' in which their experiences could be told and acknowledged. We share a history of conflict, racism and injustice and if we are serious about the 'healing of these memories', we will have to realise that more than 15 years after the end of apartheid, race is still an important factor in South African society.

By making us of the 'root metaphors and models' of drama and rhetoric, as lenses to look at the IHOM workshops, we discover that they are very useful to tackle the real crisis facing theology in a South African context, namely not so much a crisis of meaning, but one of suffering and exclusion. Wepener states that (parts of) the South African population are indeed still experiencing a process of grief and 'for an individual or group it is healthy to work through all the various phases and such a process can contribute towards achieving recovery and ultimately, reconciliation' (Wepener 2009:70). The IHOM workshops provide the 'safe spaces' for people to tell their stories in confidentiality, even giving the opportunity for confession of sin as part of the process of reconciliation.

Practical theology, in making use of the methodology of 'healing of memories', is also an example of 'good practice'. Good practice, according to Osmer (2008), provides normative guidance in practical theological interpretation in two ways:

(1) it offers a model of good practice from the past or present with which to reform a congregation's present actions; (2) it can generate new understandings of God, the Christian life, and social values beyond those provided by received tradition.

(Osmer 2008:152)

In this regard, the work of Elaine Graham (1996) on transforming practice is of special importance. She argues that transforming practice can generate new knowledge and values that cannot be formed in any other way, helping to overcome structures of domination and offering models of transcendence that is compelling to many people in a postmodern context.

Therefore, the goal of practical theology's dialogue with other fields is 'to contribute to social transformation that alleviates this suffering' (Osmer 2008:167). Drama and rhetoric are also very helpful theoretical tools to pursue what Lamb (1982) and Chopp (1987) describe in their works as a revised method of correlation, 'which situates the dialogue between theology and other fields in a broader conversation than rational exchange between academic disciplines' (Chopp 1987:120). In this regard, it is also important according to Van der Borght (2009), to realise:

South African experiences in the past and present provide us with biblical and theological arguments, motives, strategies, and structures - many to be avoided and some others to be cherished - in the search for expressions of Christianity that give space to its local and its universal aspect.

(Van der Borght 2009:24)

In terms of pedagogies of practical theology, where the question is how courses in practical theology might help students to develop the knowledge, skills and attitudes of practical theological interpretation, the IHOM workshops provide an excellent opportunity for students to learn how to 'carry out the descriptive-empirical, interpretive, normative, and pragmatic tasks in response to particular episodes, situations and contexts' (Osmer 2008:219). It is a tremendous opportunity for the students to conceptualise task competence in terms of the broader end states of practical theology and to integrate the four tasks of practical theological interpretation. At the same time, it also enhances the capacity for cross-disciplinary thinking and the ability to draw on knowledge, skills and attitudes learned in one context to address relatively novel problems in different contexts' (Osmer 2008:223). 
The methodology of IHOM also opens up the potential for empirical investigation in the form of ethnographic studies into the ecology of faith communities and other groups. Preparing these communities and groups for the future should be accompanied by a thorough empirical ethnographic investigation into their ecologies (Wepener 2009:70). Brouwer encourages practical theologians when he writes: 'We should be thinking intensively about and looking for vital ecologies and even for vital potential within less vibrant ecologies' (Brouwer 2009:5).

The fact that the IHOM workshops normally end with a participatory liturgy helps practical theologians to realise once again the importance of the place of ritual in the process of reconciliation. Rituals are not only very appropriate within this process, but also serve as channels to guide aspects like emotions and thoughts through the necessary process (Wepener 2009:71). Given the fact that the task of the TRC has been completed more than a decade ago, but that the task of reconciliation on all levels in South African is far from complete, we are in desperate need of reconciliation rituals (Cilliers \& Wepener 2007:39).

Practical theology in a South African context, according to Cilliers (2009:18), 'will by nature always be in a process of reconstruction; will remain provisional and experimental; and exists within the creative tensions of empirical research and theological conceptualization'. In investigating something like an IHOM workshop by making use of dramatic and rhetorical frameworks, the discipline is busy with 'faith in search of social embodiment'. In this regard, practical theology is busy with a bridge-crossing approach:

... taking Practical Theology beyond its exclusively ecclesiological boundaries, striving to interact with a variety of communities (including faith communities) in order to serve and enrich these communities, but also to be served and enriched by them in a collaborative and reciprocal way.

(Cilliers 2009:19)

In the last instance, practical theology is after all a theological endeavour in search of 'theological understanding'. It is, in other words, the acquisition of a kind of 'practical knowing' that constitutes a life-wisdom grounded in faith (cf. Farley 1975, 1982). Practical theology as 'healing of memories' must therefore be supplemented by a biblical-theological understanding of reconciliation, taking the research to a further level of normative reflection using 'theological concepts to interpret particular episodes, situations, or contexts, constructing ethical norms to guide our responses, and learning from "good practice"' (Osmer 2008:4).

\section{References}

Anderson, B.W., 1988, The Unfolding Drama of the Bible, 4th edn., Fortress Press, Minneapolis, MN.

Balthasar, H.U. von. 1998, Theo-Drama: Theological Dramatic Theory, vol. 5, The Last Act, Ignatius, San Francisco, CA.

Brouwer, R., 2009, 'Missional church and local constraints: A Dutch perspective', Verbum et Ecclesia 30(2), 1-5.

Brown, D., 2008, God and mystery in words: Experience through metaphor and drama, University Press, Oxford.

Burke, K., 1969, A Rhetoric of Motives, University of California Press, Berkeley, CA.

Childers, J. \& Smith, C.J. (eds.), 2008, Performance in Preaching: Bringing the sermon to life, Baker Academic, Grand Rapids, MI.

Chopp, R., 1987, 'Practical Theology and Liberation', in L. Poling \& J. Mudge (eds.), Formation and Reflection: The Promise of Practical Theology, pp. 120-138, Fortress Press, Philadelphia, PA.

Cilliers, J.H., 2009, '“Fides quarens societatum”: Praktiese teologie op soek na sosiale vergestalting', Tydskrif vir Geesteswetenskappe 49(4).

Cilliers, J. \& Wepener, C., 2007, 'Ritual and the Generation of Social Capital in Context of Poverty: A South African Exploration', International Journal of Practical Theology 11, 39-55. doi: 10.1515/IJPT.2007.4

Cloete, P. \& Kotze, F., 2009, 'Concept paper on social cohesion/inclusion in local integrated development plans', Final draft.

Farley, E., 1975, Ecclesial Man: A Social Phenomenology of Faith and Reality, Fortress Press, Philadelphia, PA.

Farley, E., 1982, Ecclesial Reflection: An Anatomy of Theological Method, Fortress Press, Phildadelphia, PA.

Graham, E., 1996, Transforming practice: Pastoral Theology in an Age of Uncertainty, Wipf and Stock, Eugene, OR.

Heidegger, M., 1977, 'Letter on Humanism', in D.F. Krell (ed.), Basic Writings, pp. 213266, Harper \& Row, New York, NY.

Institute for Healing of Memories n.d., viewed 02 June 2011, from http://www. healingofmemories.co.za.

Keifert, P., 2009, Testing the Spirits: How Theology Informs the Study of congregations, Eerdmans, Grand Rapids, MI.

Lamb, M., 1982, Solidarity with Victims: Toward a Theology of Social Trasnformation, Crossroad, New York, NY.

Lewis, I.M., 2003, Social and cultural anthropolgy in perspective, Transactions Publishers, Piscataway, NJ.

Osmer, R.R., 2005, The Teaching Ministry of Congregations, Westminster, Louisville, KY

Osmer, R.R., 2008, Practical Theology: An Introduction, Eerdmans, Grand Rapids, MI.

Quash, B., 2005, Theology and the Drama of History: Cambridge Studies in Christian Doctrine, Cambridge University Press, Cambridge.

Tracy, D., 1981, The analogical imagination: Christian theology and the culture of pluralism, Crossroads, New York, NY.

Turner, V.W. \& Turner, E., 1978, Image and Pilgrimage in Christian Culture, University Press, Columbia, NY.

Turner, V.W., 1974, Dramas, Fields and Metaphors: Symbolic Action in Human Society, Cornell University Press, Ithaca, NY and London.

Turner, V.W., 1982, From Ritual to Theatre: The Human Seriousness of Play, PA. Publications, New York, NY.

Turner, V.W., 1986, The Anthropology of Performance, PAJ Publications, New York, NY.

Van der Borght, E., 2009, 'Ras nog steeds belangrijke factor in Zuid-Afrika', Inaugural lecture delivered upon accepting the position of VU University Amsterdam Desmond Tutu Chair, pp. 1-24,VU, Amsterdam.

Vanhoozer, K., 2005, The Drama of Doctrine: A Canonical-Linguistic Approach to Christian Theology, Westminster, John Knox, Louisville, KY.

Wepener, C.J., 2009, From Fast to Feast: A Ritual-Liturgical Exploration of Reconciliation in South African Cultural Contexts. Liturgia Condenda 19, Peeters, Leuven.

Wright, N.T., 1992, The New Testament and the People of God, Fortress Press, Minneapolis, MN 